\footnotetext{
${ }^{1}$ Institute of Animal Breeding and Husbandry, Christian-Albrechts-University, Kiel, Germany

${ }^{2}$ University of Veterinary Medicine Hannover; Fieldstation for Epidemiology, Bakum, Germany
}

\author{
TANJA WEHEBRINK ${ }^{1}$, NICOLE KEMPER ${ }^{1}$, ELISABETH GROSSE BEILAGE ${ }^{2}$ and
} JOACHIM KRIETER ${ }^{1}$

\title{
Campylobacter spp.: Risk factor analysis in fattening pig farms
}

\begin{abstract}
There is a lack of information about the prevalence and origins of the important zoonotic pathogen Campylobacter spp. in the different stages of the pig production chain. The aim of this study was to gather further information about the sources of infection with Campylobacter spp. and their qualitative and quantitative importance in pig production. For statistical analysis, 1,040 results from the bacteriological examination for Campylobacter spp. were evaluated with questionnaires from four farrowing and twelve fattening units. The prevalence was determined via faeces and swab samples with regard to certain farm production parameters. Thereby $30.8 \%$ of the sows and $80.9 \%$ of their piglets were carriers of Campylobacter spp.. In the fattening unit, the prevalence at the beginning of the fattening period was $89.2 \%$ and at the end $64.7 \%$. As a result of the small sample size in the farrowing unit it was not possible to perform a risk analysis which yielded significant conclusions. In the fattening stage, the following risk factors had a significant effect $(\mathrm{p} \leq 0.05)$ on Campylobacter spp. prevalence: sampling time, number of fattening places per herd, mixed farming, floor space design, feed origin, antibacterial and anthelmintic treatment. These results show that housing and management have a possible influence on the Campylobacter spp. prevalence and should be investigated further.
\end{abstract}

Key Words: Campylobacter coli / jejuni, pig, fattening units, risk analysis, odds ratio

\section{Zusammenfassung}

Titel der Arbeit: Campylobacter spp.: Risikoanalyse in Schweinemastbetrieben

Über die Prävalenzen und Eintragsquellen des Zoonosenerregers Campylobacter spp. in den verschiedenen Produktionsstufen der Schweineerzeugung existieren bisher nur wenige Informationen. Die vorliegende Studie soll zur Aufdeckung produktionsspezifischer Risikofaktoren und ihrer Analyse hinsichtlich der qualitativen und quantitativen Bedeutung beitragen. Für die statistische Analyse wurden 1.040 Ergebnisse der bakteriologischen Untersuchung auf Campylobacter spp. im Zusammenhang mit den Informationen aus einem Fragebogen aus vier Ferkelerzeuger- und zwölf Mastbetrieben ausgewertet. Die Prävalenzen des Erregers wurden mit Hilfe von Kotund Abstrichtupferproben vor dem Hintergrund verschiedener Betriebsbedingungen ermittelt. Dabei wurden bei 33,8\% der Sauen und bei 80,9\% der Ferkel Campylobacter spp. nachgewiesen. In der Produktionsstufe Mast betrug die Prävalenz am Mastanfang 89,2\% und am Mastende 64,7\%. Aufgrund des geringen Datenmaterials konnte auf der Produktionsstufe Ferkelerzeugung keine Risikoanalyse durchgeführt werden. Folgende Faktoren hatten auf den Mastbetrieben einen signifikanten Einfluss $(\mathrm{p} \leq 0,05)$ auf die Campylobacter Prävalenz: Zeitpunkt der Probeentnahme, Anzahl Mastplätze, Mischbetrieb, Bodengestaltung, Futterherkunft, Einstallbehandlung und anthelminthische Behandlung. Die Ergebnisse veranschaulichen, dass eine Reduzierung der Campylobacter spp. Prävalenz durch betriebliche Haltungs- und Managementfaktoren möglich ist. Dieses Phänomen sollte weiter untersucht werden.

Schlüsselwörter: Campylobacter coli / jejuni, Schwein, Mastbetriebe, Risikoanalyse, Odds Ratio

Introduction

Infections caused by Campylobacter spp. (C.) are prevalent worldwide. Campylobacter jejuni and C. coli are by far the most common Campylobacter species infecting humans. Both species are associated with clinically indistinguishable diarrhoea in humans (NACHAMKIN, 2003). In Germany, the Robert-Koch-Institute 
registered 61,823 cases of humans suffering from such an infection in 2005. However, C. jejuni is implicated in about $85 \%$ of the cases of human campylobacteriosis, with the remaining cases being primarily caused by C. coli (FRIEDMAN et al., 2000).

Campylobacter spp. are part of the normal gut microflora in many food-producing animal species, including chickens, turkeys, swine, cattle and sheep (BLASER, 1997). For instance, C. jejuni is more commonly isolated from chickens and cattle, while C. coli is more common among swine (YOUNG et al., 2000). Transmission to humans appears to occur primarily through the consumption of contaminated poultry products, unpasteurised milk products and meat products (EFFLER et al., 2001; FRIEDMAN et al., 2004). In addition to the consumption of undercooked meat, cross-contamination to other food products may play a significant role in the number of illnesses observed. The infective dose (number of organisms sufficient to cause infection) in humans can be very low. Only 800 colony-forming units of specific strains can lead to Campylobacter infection (BLACK, 1988).

According to the regulations of the "White Paper on Food Safety" (EUROPÄISCHES WEISSBUCH ZUR LEBENSMITTELSICHERHEIT, 2000), the farmer and the participating manufacturing industry in the food production should have the main responsibility for food safety. Now and in future, this adds up to the demand for preventive measures in primary production following the principle "from the producer to the consumer". This leads to a consolidated need for the detection of relations between pathogen prevalence in the herds and the herd management and husbandry. Determination of various important entry routes and spreading factors provides useful decision guidance for all production units in the meat production chain to minimise the transmission of zoonotic pathogens. For these reasons, this study was conducted with the aim to determine the prevalence of Campylobacter spp. in farrowing and fattening units by the collection of faeces and rectal swabs. Further risk factors for the occurrence of Campylobacter spp. in farrowing and fattening units should be observed via environmental and feed samples from the checked herds and questionnaires in the corresponding pig farms.

\section{Material and Methods}

Four farrowing and twelve fattening farms provided the basis for the present study. The sampling size on every farm was calculated according to the formula from NOORDHUIZEN et al. (1997). In total, 1.040 faecal or swab samples respectively from pigs of all ages from farrowing and fattening units were analysed. Additionally, 56 environmental and feed samples were collected.

Cultural methods were used to test all samples for Campylobacter spp., including the differentiation of subspecies. The bacterial detection of Campylobacter spp. proceeds from ISO 10272 (1995) with following biochemical differentiation of C. coli and C. jejuni.

Calculation of the intraherd and animal prevalence and the 95\%-confidence intervals within the production stage was performed with the PROC SURVEYMEANS procedure from SAS ${ }^{\circledR}$ (2002).

On every farrowing and fattening farm, data collection was carried out with the aid of a questionnaire. Besides the general farm information, detailed data about the housing system, management, state of health and aspects of disease surveillance were acquired. 
In consideration of the bacteriological results, these data contributed to a hazard analysis to detect the origin and spread of Campylobacter spp. infections.

The statistical analysis was performed with a generalised linear model. At first the management-specific parameters were tested respectively with the $\chi^{2}$-test regarding the influence on the pathogen prevalence. Every parameter having a value $p<0.3$ in the $\chi^{2}$ test and an adequate distribution was included in the generalised linear model. The GENMOD procedure from the software package SAS ${ }^{\circledR}$ (2002) was reviewed for significance $(\mathrm{p} \leq 0.05)$. For the estimation, a binomial distribution and a logistic link function (i.e. logistic regression) were assumed. As a result of the small sample size in the farrowing unit, it was not possible to perform a risk analysis which yielded significant conclusions. From the fattening unit, the following fixed effects were considered in the model: sampling time (growing pigs, finishing pigs), herd organisation (number of fattening places, mixed farming), housing system and forage (floor space design, feed origin) and health (antibacterial and anthelmintic treatment). The estimates (ê) from the risk factors were transformed into odds ratios (OR=exp (ê)) and the 95\%-confidence intervals were calculated. A low absolute frequency in the least sub classes from some factors did not allow a statistical analysis with logistic regression. For the factors having a p-value $\leq 0.05$ in the $\chi^{2}$-test, the odds ratios and 95\%-confidence intervals were calculated separately.

\begin{abstract}
Results
Prevalence

Sows and suckling pigs

Campylobacter (C.) spp. were isolated in 33.8\% of the sows and in $80.9 \%$ of the piglets (Figure 1). Neither pathogen was isolated from the environmental and feed samples.
\end{abstract}

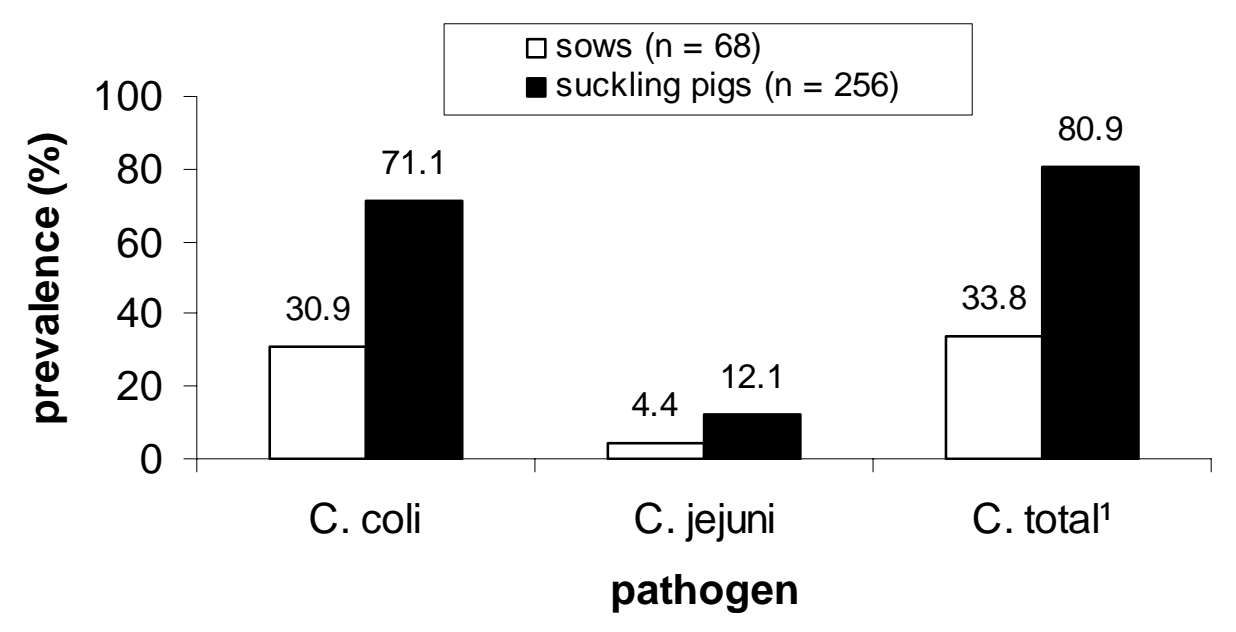

${ }^{1}$ C. total $=$ C. coli and/or C. jejuni

Fig. 1: Prevalence of Campylobacter spp. in sows and suckling pigs (Prävalenz von Campylobacter spp. bei Sauen und Saugferkeln)

Table 1 shows the prevalence of Campylobacter spp. in pigs of the farrowing unit at herd level. Notable is the fact that in herd 4 no sows are carriers of the pathogen but 
some of their piglets are. In herd 3, no piglets were sampled, therefore no results for this production stage appear in Table 1.

Table 1

Prevalence of Campylobacter spp. in pigs of the farrowing unit at herd level (Prävalenz von Campylobacter spp. in der Ferkelerzeugung auf Betriebsebene)

\begin{tabular}{|c|c|c|c|c|c|}
\hline & & \multicolumn{2}{|c|}{ sows $^{1}$} & \multicolumn{2}{|c|}{ suckling pigs ${ }^{2}$} \\
\hline & & prevalence (\%) & $95 \%-\mathrm{CI}^{3}$ & prevalence (\%) & $95 \%-C I$ \\
\hline \multirow[t]{3}{*}{ herd 1} & C. coli & 23.5 & $1.1-46.0$ & 96.5 & $92.5-100.0$ \\
\hline & C. jejuni & - & - & - & - \\
\hline & C. total $^{4}$ & 23.5 & $1.1-46.0$ & 96.5 & $92.5-100.0$ \\
\hline \multirow[t]{3}{*}{ herd 2} & C. coli & 94.1 & $81.6-100.0$ & 95.3 & $90.8-99.9$ \\
\hline & C. jejuni & - & & - & - \\
\hline & C. total & 81.6 & $81.6-100.0$ & 95.3 & 90.8-99.9 \\
\hline \multirow[t]{3}{*}{ herd 3} & C. coli & 5.9 & $0-18.4$ & - & - \\
\hline & C. jejuni & 17.6 & $0-37.9$ & - & - \\
\hline & C. total & 17.6 & $0-37.9$ & - & - \\
\hline \multirow[t]{3}{*}{ herd 4} & C. coli & not sampled & not sampled & 21.2 & $12.3-30.0$ \\
\hline & C. jejuni & not sampled & not sampled & 36.5 & $26.0-46.9$ \\
\hline & C. total & not sampled & not sampled & 50.6 & $39.7-61.4$ \\
\hline
\end{tabular}

Fattening pigs

The prevalence of Campylobacter spp. in growing pigs was $89.2 \%$ and in finishing pigs slightly lower with $64.7 \%$ (Figure 2). Neither pathogen was isolated from the environmental and feed samples.

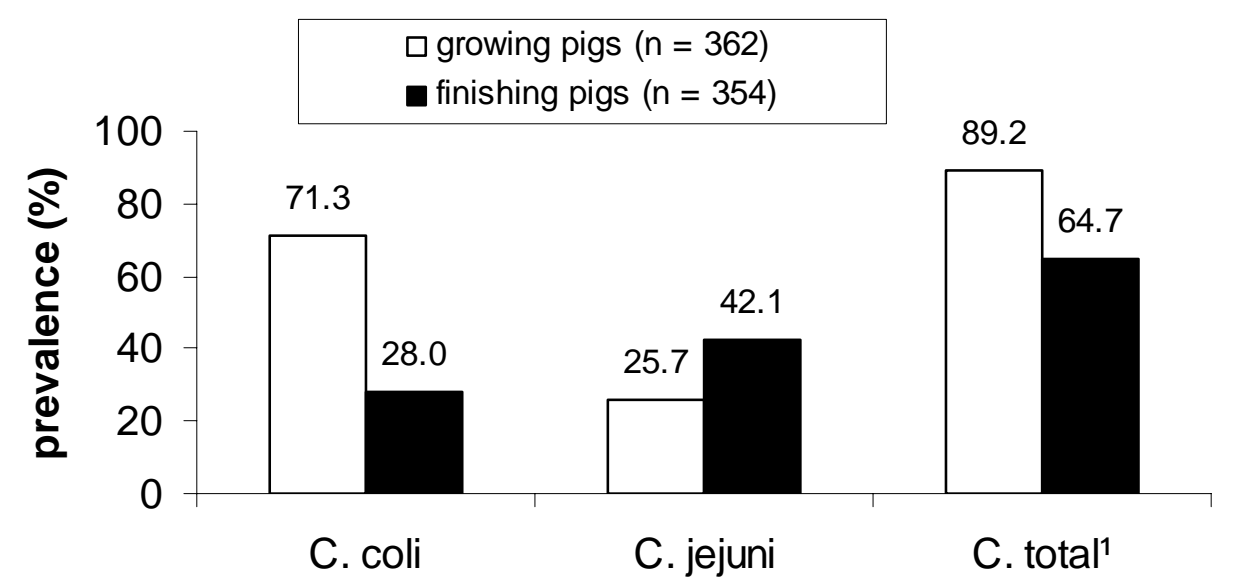

pathogen

${ }^{1}$ C. total $=\quad$ C. coli and $/$ or $C$. jejuni

Fig. 2: Prevalence of Campylobacter spp. in growing and finishing pigs (Prävalenz von Campylobacter spp. am Mastanfang bzw. Mastende)

Campylobacter spp. were detected on all farms in growing and finishing pigs (Figure 3). Herd 10 was the farm with the lowest Campylobacter spp. prevalence (54.8\% in growing pigs and $19.4 \%$ in finishing pigs). In herd 9, no growing pig was pathogen- 
free $(n=29)$. There was still a high prevalence at the second sampling time in comparison to the other herds with $81.5 \%$. Nearly the same results were achieved by herd 12 with $100 \%$ ( $\mathrm{n}=31$ ) carriers of Campylobacter spp. at the beginning of fattening period and $80.6 \%$ at the end of growing time. In every herd the prevalence decreased from the first sampling time to the second. Only in herd 3 did the prevalence increase from $75.9 \%$ to $86.2 \%$.

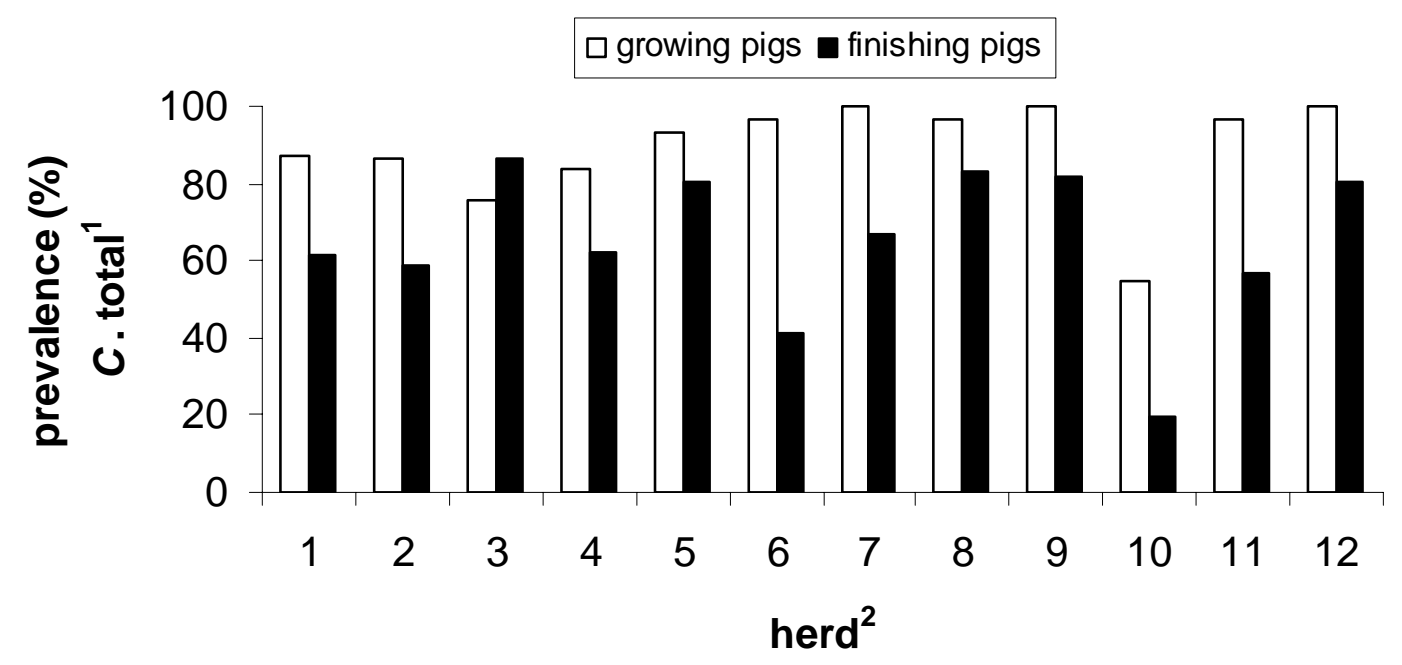

${ }^{1}$ C. total $=$ C. coli and $/$ or $C$. jejuni

${ }^{2}$ herd $=29$ to 31 sampled pigs per herd

Fig. 3: Prevalence of Campylobacter spp. in the fattening pigs at herd level (Prävalenz von Campylobacter spp. bei Mastschweinen auf Betriebsebene)

\section{Risk factors}

For the statistical risk factor analysis in the fattening unit, 716 results from the bacteriological examination were evaluated in context with the questionnaire data from the twelve fattening herds. Twenty factors were tested regarding their influence on the prevalence of Campylobacter. Significant effects were shown for the following factors: sampling time, number of fattening places, mixed farming, floor space design, feed origin, antibacterial and anthelmintic treatments (Table 2).

Over the fattening period the Campylobacter spp. prevalence decreased. At the beginning the odds ratio increased by a factor of 4.46 (Table 2).

The risk factor fattening places per herd was differentiated between farms size under 1000 pigs and alternatively over 1000 pigs. The bacteriological results show that pigs from farms with less than 1000 fattening places had a prevalence of $80.0 \%$ and those from larger farms a prevalence of $74.3 \%$. The chance to isolate Campylobacter spp. from pigs from smaller herds increased by a factor of 1.44 .

Housing in separated stalls is another preventive influence. When the animals on mixed farms were kept in separated stalls the chance of a positive bacteriological result decreased $(\mathrm{OR}=0.61)$. 
Pigs which were kept on a plan floor without bedding had the highest prevalence in comparison to the other flooring systems. In this housing system, the chance of obtaining a positive result was highest.

Table 2

Significant risk factor and further risks factors: fattening unit (Signifikante Risikofaktoren und weitere Einflussfaktoren bei Mastschweinen)

\begin{tabular}{|c|c|c|c|c|}
\hline risk factor & p-value & prevalence (\%) & $\mathrm{OR}^{1}$ & $95 \% \mathrm{CI}^{2}$ \\
\hline \multicolumn{5}{|l|}{ date } \\
\hline sampling time & $<.0001$ & & & \\
\hline$\overline{\text { growing pigs }}$ & & 89.2 & 4.64 & 3.11-6.93 \\
\hline finishing pigs & & 64.7 & 1 & - \\
\hline \multicolumn{5}{|l|}{ herd organisation } \\
\hline number of fattening places & 0.052 & & & \\
\hline$<1000$ places & & 80.0 & 1.44 & $1.00-2.08$ \\
\hline > 1000 places & & 74.3 & 1 & - \\
\hline mixed farming & 0.015 & & & \\
\hline stall separated & & 74.6 & 0.61 & $0.41-0.92$ \\
\hline stall not separated & & 82.0 & 1 & - \\
\hline \multicolumn{5}{|l|}{ housing system and forage } \\
\hline floor space design & 0.001 & & & \\
\hline fully slatted floor & & 74.4 & 0.35 & $0.20-0.95$ \\
\hline$<50 \%$ slatted floor & & 74.8 & 0.56 & $0.32-0.97$ \\
\hline plan floor without bedding & & 84.7 & 1 & - \\
\hline feed origin & 0.001 & & & \\
\hline$\overline{\text { own forage }}$ & & 70.3 & 0.41 & $0.24-0.68$ \\
\hline purchase forage & & 79.4 & 1 & - \\
\hline \multicolumn{5}{|l|}{ health } \\
\hline antibacterial treatment & 0.028 & & & \\
\hline$\overline{\text { yes }}$ & & 74.6 & 0.66 & $0.45-0.96$ \\
\hline no & & 79.7 & 1 & - \\
\hline anthelmintic treatment & 0.003 & & & \\
\hline$\overline{\text { yes }}$ & & 83.9 & 1.99 & $1.25-3.18$ \\
\hline no & & 74.8 & 1 & - \\
\hline \multicolumn{5}{|l|}{ source $^{3}$} \\
\hline$\overline{\text { own piglets }}$ & & 73.3 & 0.26 & $0.09-0.75$ \\
\hline steadier farrowing herds & & 76.1 & 0.32 & $0.13-0.76$ \\
\hline purchase breeding herds & & 90.3 & 1 & - \\
\hline \multicolumn{5}{|l|}{ feed consistency $^{3}$} \\
\hline meal & & 70.3 & 0.63 & $0.42-0.96$ \\
\hline granule & & 81.0 & 1.23 & $0.60-2.54$ \\
\hline pellets & & 78.0 & 1 & - \\
\hline \multicolumn{5}{|l|}{ blank dwell time ${ }^{3}$} \\
\hline$>10$ days & & 90.5 & 3.53 & $1.82-6.86$ \\
\hline$<10$ days & & 74.5 & 1 & - \\
\hline
\end{tabular}

An antibacterial treatment at the beginning of the fattening period was implemented on seven herds. The following antibiotics were used for this treatment: Amoxicillin, Tetracycline and Sulfonamide. The chance of a positive finding decreased when the animals were treated with antibacterial substances during this time period $(\mathrm{OR}=0.66)$. On four herds, anthelmintics were used at the beginning of fattening period. The appliance of Ivermectin, Flubendazol and Levamisolhydrochlorid was adopted for 
deworming. The chance of obtaining a positive result rose by a factor of 1.99 when anthelmintics were administered.

Further risk factors "source of piglets", "feed consistency" and "blank dwell time" had an influence on the prevalence of Campylobacter spp., too. The chance of obtaining a positive result from the bacteriological investigation was smaller from fattening pigs in a closed herd system $(\mathrm{OR}=0.26)$. Furthermore, the following cases were preventive: feeding meal $(\mathrm{OR}=0.63)$ instead of granule or pellets and blank dwell time under 10 days.

\section{Discussion}

The results from the present study prove that Campylobacter spp. are of increasing importance in farrowing and fattening units: high prevalence of Campylobacter spp. were found in suckling, growing and finishing pigs (WEHEBRINK, 2006). Other studies also confirm these results (KASIMIR, 2005; GAULL, 2002).

The occurrence of Campylobacter spp. in subsequent samples of pigs and sows was often variable in this analysis. As known from further studies the Campylobacter spp. prevalence may vary because the physiological status of the animal and external factors can influence the intestinal flora. The ability of Campylobacter spp. to colonise the intestinal tract of pigs is probably subject to the various factors influencing the colonisation resistance of the gut (RUCKEBUSCH et al., 1991). Furthermore, the virulence of the Campylobacter spp. strains (re)infecting the pigs may also alter the bacteriological results (WEIJTENS et al., 1999).

The prevalence estimates on basis of bacterial findings must be questioned critically. Because of the intermittent shedding at animal level the bacterial detection in faecal samples can create a false image of the prevalence at herd level. Additionally, during sampling and laboratory processing, the pathogen's sensibility to environmental influences can decrease the detection rate.

The bacteriological analysis showed that in some herds as far as $100 \%$ of the pigs had contact with Campylobacter spp.. In contrast to YOUNG et al. (2000), a successful abatement strategy can be doubted due to high general prevalence and the infection of piglets during the first weeks of life.

Based on the zoonotic directive (Nr. 2160/2003), a monitoring for Campylobacter spp. is mandatory. It should take place at an adequate stage of the food chain. Control has to be directed primarily at the prevention of colonisation of farm animals by means of the implementation of Good Hygienic Practice (GHP), biosecurity measures and husbandry practices incorporating Hazard Analysis Critical Control Point (HACCP) based on risk management systems (WHYTE et al., 2002). Because of this, the objective of this study was to obtain more information about the risk factors influencing the prevalence of this pathogen. As a result of the small sample size in the farrowing unit, it was not possible to perform a risk analysis which yielded significant conclusions. In the fattening unit the attention was focused additionally on risk factors which do not reach the significant limitation of the $5 \%$ probability error because of the small sample size. Effects which exceeded the housing and management factors were not acquired in the questionnaire and could not consequently be regarded in the evaluation. Because of this the results should only be regarded as tendencies.

One important influencing factor could be the sampling time. Because of the steady state of immunity the chance of a positive Campylobacter spp. result is higher in 
growing pigs than to finishing pigs. Additionally, transport stress, changing the forage and status conflicts can raise the faecal shedding of this pathogen in growing pigs.

In contrast to recent studies, risk factor analysis in the fattening unit demonstrated a significant influence on the Campylobacter spp. detection rate for the "number of fattening places". The chance of obtaining a positive Campylobacter spp. result is higher when animals are held in smaller herds ( $<1000$ places). This result did not conform to GAULL (2002). He detected that the factor "number of animals" hardly has any influence on Campylobacter spp.-positive animals.

Separating the herds in "mixed farming" is a useful method to decrease pathogen transmission. In contrast to our study, BOES et al. (2005) could not assert this effect: investigation of the occurrence and diversity of $C$. jejuni infections in finisher pigs in herds with combined cattle or poultry production and herds only producing pigs showed no evidence of transmission of $C$. jejuni from cattle or poultry to pigs in mixed production herds. Herd prevalence of $C$. jejuni was $8.3 \%$, whereas $C$. jejuni and $C$. coli were isolated from $0.8 \%$ and $92.0 \%$ of pigs, respectively. In mixed production herds, C. jejuni predominated in cattle (42.7\%) and poultry (31.6\%), whereas C. jejuni was only isolated from $1.3 \%$ to $2.5 \%$ of pigs in these herds.

A lower Campylobacter spp. detection rate is not promoted by a plan floor without bedding and purchase forage. One reason for the higher prevalence in housing systems with plan floor is the intensive contact of the pigs with their faeces for a longer time. With regard to purchased forage, the origin is often uncertain: whether the forage comes directly from the forage producer or whether several forage chandlers are interposed, increasing the risk of contamination, remains often unknown.

A further result from the questionnaire analysis was that an arranged antibacterial treatment but no anthelmintic treatment was preventive against Campylobacter spp. infections. This results must be questioned critically because it is not known first which health status in detail can be found in the different herds and, second, what the antimicrobial resistance of Campylobacter spp. is. Further studies will be needed to explain these two risk factors.

Despite the fact that forage in granule form is heated during the manufacturing process, the chance of obtaining a positive Campylobacter spp. result rose by a factor of 1.23 in this form of forage feeding.

The fact that a blank dwell time under ten days is better for the pathogen prevalence than a blank dwell time over ten days can be related to recontamination after disinfection and cleaning.

Other studies found risks factors which could not be proven in this study. For example, GAULL (2002) discovered that a factor such as different "husbandry" hardly has any influence on Campylobacter spp.-positive animals. "Feed" and "number of pig delivering farms" are not risk factors either (WEIJTENS et al., 1993). SCHUPPERS et al. (2005) detected that important risk factors contributing to the prevalence of resistance strains were shortened tails, lameness, skin lesions, feed without whey, and ad libitum feeding. Multiple antimicrobial resistance was more likely in farms which only partially used an all-in-all-out system, or a continuous-flow system compared to a strict all-in-all-out animal-flow. Presence of lameness, ill-thrift, and scratches at the shoulder in the herd also increased the odds for multiple resistance. Thus, the results from SCHUPPERS et al. (2005) showed that on finishing farms which maintained a 
good herd health status and optimal farm management the prevalence of antimicrobial resistance was also more favourable.

In the present study, only a few factors could be identified as potential risk factors. For further clarification of risk factors comprehensive assessment and transmission devolution studies are required.

\section{Acknowledgement}

This research was financially supported by the H. Wilhelm Schaumann-Stiftung, the Ministerium für Soziales, Gesundheit, Familie, Jugend und Senioren des Landes Schleswig-Holstein and the Arbeitsgruppe Lebensmittelqualität und -sicherheit (QUASI) from the Faculty of Agricultural and Nutritional Science, ChristianAlbrechts-University, Kiel.

\section{References}

BLACK, R.E.; LEVINE, M.M.; CLEMENTS, M.L.; HUGHES, T.P.; BLASER, M.J.: Experimental Campylobacter jejuni infection in humans. J. Infect Dis. 157 (1988) 3, 472-479

BLASER, M.J.:

Epidemiologic and clinical features of Campylobacter jejuni infections. J. Infect Dis. 176 (1997) (Suppl. 2), S103-S105

BOES, J.; NERSTING, L.; NIELSEN, E.M.; KRANKER, S.; ENØE, C.; WACHMANN, H.C.; BAGGESEN, D.L.:

Prevalence and Diversity of Campylobacter jejuni in Pig Herds an Farms with and without Cattle or Poultry. J. Food Prot. 68 (2005), 722-727

EFFLER, P.; IEONG, M.C.; KIMURA, A.; NAKATA, M.; BURR, R.; CREMER, E.:

Sporadic Campylobacter jejuni infections in Hawai: associations with prior antibiotic use and commercially prepared chicken. J. Infect Dis. 183 (2001) 7, 1152-1155

FRIEDMAN, C.R.; NEIMANN, J.; WEGENER, H.C. TAUXE, R.V.:

Epidemiology of Campylobacter jejuni infections in the United States and other industralized nations. In: Nachamkin, I.; Blaser, M.J.: Campylobacter. 2nd ed. Washington, D.C.: American Society for Microbiology Press. 121-38

FRIEDMAN, C.R.; HOEKSTRA, R.M.; SAMUEL, M.; MARCUS, R.; BENDER, J.; SHIFERAW B.:

Risk factors for sporadic Campylobacter infections in the united states: a case-control studie in FoodNet sites. Clin Infect Dis. 38 (2004) (Suppl. 3), S285-S296

GAULL, F.:

Vorkommen thermophiler Campylobacter spp. bei Schweinen im Betrieb und auf dem Schlachthof, auf Putenschlachttierkörpern und in Lebensmitteln tierischen Ursprungs - Typisierung der Isolate mit molekularbiologischen Fingerprintingmethoden und Vergleich der Isolate untereinander und mit humanen Isolaten. Leipzig, Veterinärmed. Fak., Diss. (2002)

INTERNATIONAL ORGANIZATION FOR STANDARDIZATION: International Standard 10272 (1995)

KASIMIR, S.:

Verlaufsuntersuchungen zum Vorkommen potentiell humanpathogener Yersinia enterocolitica und Campylobacter spp. in Schweinebeständen von der Geburt bis zur Schlachtung sowie Genotypisierung ausgewählter Isolate. Leipzig, Veterinärmed. Fak., Diss. (2005)

NACHAMKIN, I.:

Campylobacter and Arcobacter. In: Murray, P.R.; Baron, E.J.; Pfaller, M.A.; Jorgensen; J.H.; Yolken, R.H.: Manual of clinical microbiology, ASM Press, Washington, DC (2003), 902-914

NOORDHUIZEN, M.; FRANKENA, K.; GRAAT, E.: Animal health care and public health issues. In: World Congress on Food Hygiene, The Hague/Netherlands, Proc., 59 (1997)

ROBERT-KOCH-INSTITUT: Epidemiologisches Bulletin Nr. 3 (2006)

RUCKEBUSCH, Y.; PHANEUF, L.P.; DUNLOP, R.: Microflora and immunology of the digestive tract. In Physiology of Small and Large Animals ed. RUCKEBUSCH; Y.; PHANEUF, L.P.; DUNLOP, R., Philadelphia: Becker (1991), 198-208 
SAS INSTITUTE INC.:

User's Guide (release 8.1.), Cary, NC, USA (2002)

SCHUPPERS, M.E.; STEPHAN, R.; LEDERGERBER, U.; DANUSER, J.; BISSING-CHOISAT, B.; STÄRK,

K.D.C.; REGULA, G.:

Clinical herd health, farm management and antimicrobial resistance in Campylobacter coli an finishing pig farms in Switzerland. Prev. vet. Medc. 69 (2005), 189-202

VERORDNUNG (EG) NR. 2160/2003

des Europäischen Parlaments und des Rates vom 17. November 2003 zur Bekämpfung von Salmonellen und bestimmten anderen durch Lebensmittel übertragbaren Zoonoseerregern

WEHEBRINK, T.; KEMPER, N.; GROSSE BEILAGE, E.; KRIETER, J.: Prevalence of Campylobacter spp. and Yersinia spp. in the pig production. Prev. Vet. Med. (submitted)

WEIJTENS, M.J.B.M.; BIJKER P.G.H.; VAN DER PLAS, J.; URLINGS, H.A.P.; BIESHEUVEL, M.H.: Prevalence of campylobacter in pigs during fattening; an epidemiological study. Vet. Quart. 15 (1993), 138-143

WEIJTENS, M.J.B.M.; REINDERS, R.D.; URLINGS, H.A.P.; VAN DER PLAS, J.:

Campylobacter infections in fattening pigs; excretion pattern and genetic diversity. J. Appl. Microbiol. 86 (1999), 63-70

WEISSBUCH ZUR LEBENSMITTELSICHERHEIT:

Kommission der Europäischen Gemeinschaft; Brüssel, 12 Januar 2000; KOM (1999) 719 endg.

WHYTE, P.; BOLTON , D.; O’MAHONY, H.; COLLINS, J.D.:

Development and Application of HACCP in Broiler Production and Slaughter, University College Dublin, 2002

YOUNG, C.R.; HARVEY, R.; ANDERSON, R.; NISBET, D.; STANKER, L.H.:

Enteric colonisation following natural exposure to Campylobacter in pigs. Res Vet Sci 68 (2000) 1, 7578

Received: 2007-01-07

Accepted: 2007-03-26

Authors' addresses

M.Sc. agr. TANJA WEHEBRINK, Dr. med. vet. NICOLE KEMPER,

Prof. Dr. JOACHIM KRIETER*

Institute of Animal Breeding and Husbandry, Christian-Albrechts-University,

Herrmann-Rodewald-Strasse 6, 24118 KIEL, GERMANY

* Corresponding Author, E-Mail: jkrieter@tierzucht.uni-kiel.de

Priv. Doz. Dr. med. vet. ELISABETH GROSSE BEILAGE

University of Veterinary Medicine Hannover; Fieldstation for Epidemiology,

Buescheler Strasse 9, 49456 BAKUM, GERMANY 